\title{
Flexible 3D structure of Bos taurus tyrosyl-tRNA synthetase suggests the existence of the hinge mechanism provided by conservative Gly353 at interdomain linker
}

\author{
N. A. Pydiura, A. I. Kornelyuk \\ Institute of Molecular Biology and Genetics, NAS of Ukraine \\ 150, Akademika Zabolotnoho Str., Kyiv, Ukraine, 03680 \\ kornelyuk@imbg.org.ua
}

\begin{abstract}
Mammalian tyrosyl-tRNA synthetase is composed of two structural modules: $N$-terminal catalytic miniTyrRS and non-catalytic cytokine-like C-terminal module connected by a flexible peptide linker. Till now, the 3D structure of any full-length mammalian TyrRS has not been solved by X-ray crystallography. The aim of this work was a homology modeling of 3D structure of full-lehgth B.taurus tyrosyl-tRNA synthetase. Methods. Homology modeling of TyrRS was performed by Modeller 9.1 package. Quality of the models was assessed using Biotech Validation Suite web-server. Results. Our BLAST search identified 34\% sequence homology between interdomain linker of TyrRS and linker of human c-Abl tyrosine kinase. In order to model the full-length TyrRS structure we assembled the models of three parts of the protein ( $N$ - and $C$ - terminal domains and the linker) using Modeller 9.1 software. The best Abl-17 model structure was refined by energy minimization. Conclusions. High flexibility of the interdomain linker can generate multiple conformations of TyrRS. The hinge mechanism at interdomain linker may be provided by conservative Gly353. It is proposed, that due to the linker flexibility an open extended conformation of TyrRS could transform into closed conformations in the enzyme-substrate complexes.
\end{abstract}

Keywords: tyrosyl-tRNA synthetase, homology modeling, interdomain linker, c-Abl tyrosine kinase, EMAP II, $t R N A^{T y r}$

Introduction. Tyrosyl-tRNA synthetase (TyrRS, EC 6.1.1.1) is one of the key enzymes of protein biosynthesis in both pro- and eukaryotes [1]. Bovine (B. taurus) cytoplasmic TyrRS is one of the best studied mammalian aminoacyl-tRNA synthetases. This enzyme forms a homodimer of two $59.2 \mathrm{kDa}$ subunits, each of 528 amino acid (aa) residues. N- and C-terminal domains of the enzyme subunit are connected by a long disordered 17 aa linker (Fig. 1, a) [1]. The $\mathrm{NH}_{2}$-terminal catalytic domain comprises a «minimal» $39 \mathrm{kDa}$ TyrRS and has full catalytic activity in vitro $[1,2]$. The C-terminal domain formed by aa residues Val363Ser528 is 166 aa long [3] and reveals the $52.7 \%$ identity to the mammalian cytokine endothelial monocyteactivating polypeptide II (EMAPII) [4, 5], which activates monocytes and endothelial cells - an effect first discovered at cancerogenesis induced with chemicals $[6,7]$.

(c) Institute of Molecular Biology and Genetics, NAS of Ukraine, 2012
A multiple alignment of $\mathrm{C}$-domains guided by predicted secondary structure revealed two independent subdomains (folds): a $\beta$-pleated Myf domain (OB-fold, residues Val363-Lys470) and $\alpha$-helical sub-domain (residues Gly471-Ser528) [3]. Myf domain and $\alpha$-helical sub-domain form the RNA binding surface. A lysinerich cluster KPKKK located within the sub-domain may play a role of a nuclear localization signal [8]. Several organisms posess C-terminal domain homologous to that of TyrRS. There are experimental data showing involvement of Arc1p (G4p1) from Saccharomyces cerevisiae (55.3\% identity) [10], human p43 (proEMAPII) (62.7\%) [3], and ARCE from Euplotes octocarinatus $(52 \%)$ [11] in non-specific tRNA binding. These proteins direct tRNA to the active sites of corresponding aminoacyl-tRNA synthetases $[10,12]$. It is possible, that during the evolution C-terminal domain was transferred to several diverse proteins involved in translation (such as TyrRS, MetRS, p43, and 


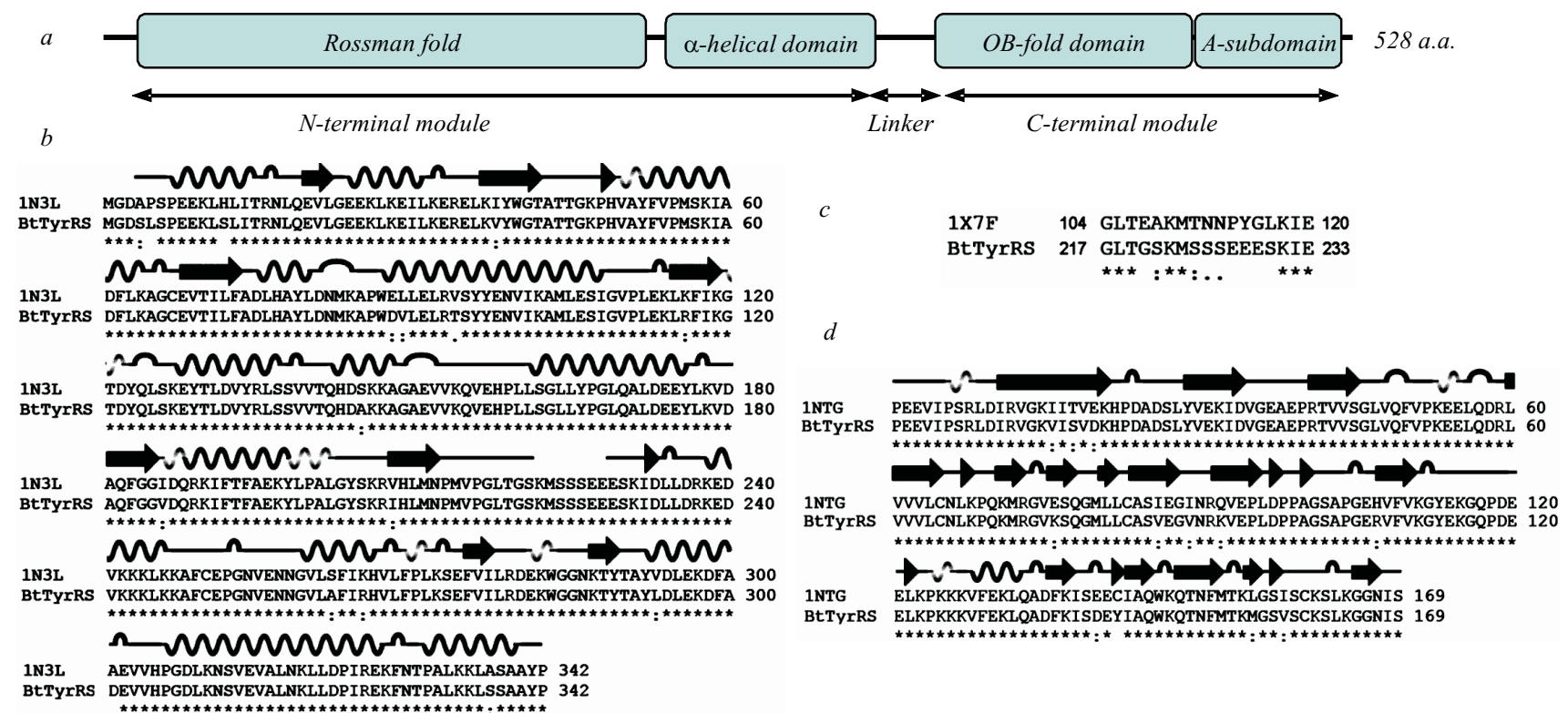

Fig. 1. $a$-Schematic representation of a single subunit domain organization of Bos taurus cytoplasmic TyrRS (Rossmann fold of the N-terminal domain is followed by the anticodon binding $\alpha$-helical fold; the interdomain linker of 17 aa links $\mathrm{N}$-module to the $\mathrm{C}$-terminal domain comprised of the OB-fold and A-subdomain); $b$ - pairwise sequence alignment of the bovine TyrRS N-terminal domain with the corresponding human sequence (PDB code 1N3L); $c$ - sequence alignment between the catalytic loop sequence of N-terminal domain of TyrRS and the uncharacterized protein from Bacillus cereus loop (PDB code 1X7F); $d$ - the alignment of the sequences of bovine TyrRS C-terminal domain with the corresponding human sequence (PDB code 1NTG_A). The alignment was made by ClustalW2 program [23, 24], the secondary structure information was obtained from PDB

Arc1p) to enable their proper functioning in higher eukaryotes [3]. Bovine C-domain contributes about $50 \%$ of TyrRS affinity to ribosomal RNAs. RNA binding has a certain specificity: among others, poly $(G)$ has the most inhibitory effect in the reaction of tRNA ${ }^{\text {Tyr }}$ aminoacylation [13].

At present there are more than 40 three-dimensional structures of diverse aminoacyl-tRNA synthetases deposited in PDB. Unfortunately, no structure of full-length mammalian TyrRS has been solved by experimental means. The difficulties of obtaining crystals can be caused by the presence of transiently disordered labile 17aa long linker between $\mathrm{N}$ - and $\mathrm{C}$-terminal domains. A large size of the protein makes NMR approach to the structure determination difficult, if not altogether impractical. Mobility and flexibility of this linker may be required for the adaptable orientation of domains necessary for aminoacylation reaction. It is noteworthy that the linker is accessible to specific proteinases and contains a putative proteolytic PEST sequence [8]. Despite all the experimental information gathered up to date, there is no clear understanding either $\mathrm{C}$-domain or interdomain linker role and mode of action. The significan- ce of linker relation to both cytokine motives and tRNAbinding domains is unclear and needs to be explained. The absence of experimentally derived full-length structure and importance of understanding a role of these two eukaryotic cytokine motives justify computational approach to the study of mammalian cytoplasmic TyrRS. An accurate model will allow further investigation of TyrRS properties, suggest biochemical, biophysical and computational experiments and may lead to elucidation of its mechanism of action.

Materials and methods. The amino acid sequence of bovine TyrRS was reported earlier [3, 9] (Entrez (http://www.ncbi.nlm.nih.gov/entrez/), accession number Q29465). The sequence has been analyzed for possible intrinsically disordered regions by DISPROT predictor VSL2B (http://www.ist.temple.edu/disprot/ predictorVSL2.php) [14] and IUPPRED (http://iupred. enzim.hu/) [15] web-servers.

We used Internet web-servers such as BLAST (http: //www.ncbi.nim.nih.gov/BLAST) and PDB-BLAST (http://www.ebi.ac.uk/pdb) to search for homologous sequences. Three-dimensional coordinates of the protein structural templates were downloaded from Protein 


\section{$a$

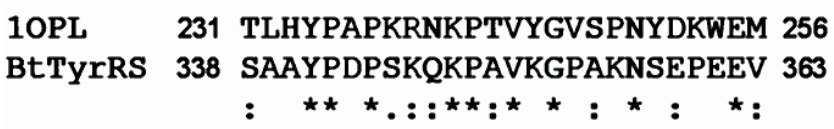

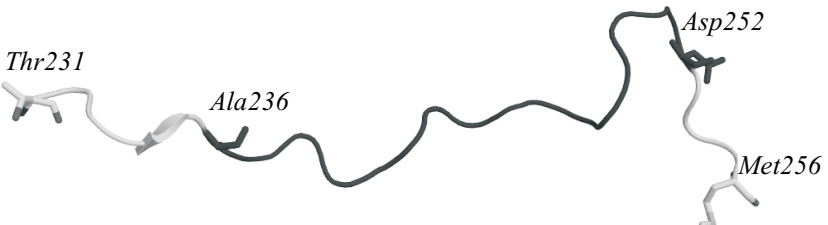

Fig. 2. $a$-Alignment of the sequences of bovine TyrRS interdomain linker with the linker derived from auto-inhibitor of human C-Abl tyrosine kinase (PDB code 1OPL_A); $b$ - 3D structure of the human C-Abl kinase linker, residues Ile229-Met256 (PDB code 1OPL_A). The structure corresponding to the TyrRS linker is shown in magenta

Data Bank (PDB) (http://www.pdb.org/pdb) [16]. A rigid alignment of TyrRSs 3D structures was carried out using function «Fit/Iterative Magic Fit/ $\mathrm{C}_{\alpha}$ atoms only» of Swiss-PdbViewer 4.0.1 (http://expasy.org/spdbv/) [17]. Images were prepared with PyMOL software [18] and POV-Ray [19]. Electrostatic potentials were calculated using APBS [20, 21].

To build 3D models of full-length bovine TyrRS we used homology modeling techniques [22]. Multiple alignments were done using ClustalW server (http:// www2.ebi.ac.uk/clustalw/) [23, 24]. A search for homologues was performed using above described tools and the resulting templates were used to model TyrRS by Modeller 9.1 package [25]. Quality of the models was assessed using Biotech Validation Suite web-server (http: //biotech.ebi.ac.uk). Ramachandran plots were built using PROCHECK [26].

Our approach to full-length TyrRS modeling can be outlined as follows: separate prediction of $\mathrm{N}$ - and C-domains 3D structures based on experimentally solved highly homologous structures, prediction of interdomain linker followed by the assembly of full-length protein models.

Both domains of bovine TyrRS are well studied and their sequences bear high degree of homology to corresponding human TyrRS domains. We used two crystallographic structures deposited in PDB (codes 1N3L and 1NTG, chain A) as templates for homology modeling of the bovine $\mathrm{N}$ - and $\mathrm{C}$-terminal domains correspondingly $[27,28]$. These pairs of sequences are highly homologues and their modeling causes no significant problem. An alignment of bovine N-terminal domain to human $1 \mathrm{~N} 3 \mathrm{~L}$ is shown on Fig. $1, b$. The homology between the two domains is $95 \%$.

A crystal structure of the human N-terminal domain reported as 1N3L lacks 7 aa of the catalytic loop. We op- ted not to close this loop de novo, but instead searched for homologues in the PDB. The PDB was queried by a catalytic loop sequence plus 5 -aa overhangs at each side: GLTGSKMSSSEEESKID. The search resulted in about 100 sequences with 70 unique ones. The sequences with low homology to catalytic loop itself were discarded. The best homologues were selected for further analysis (PDB codes $2 \mathrm{BBO}$ (chain A, human Nbd1 with Phe508), 2DBG (chain A, pyrin Paad-Dapin domain), 1PS9 (chain A), 1POY (chain 1, spermidine-putrescine-binding protein), 1X7F (chain $\mathrm{A}$, an uncharacterized Bacillus cereus protein)). Two structures, 1X7F and $1 \mathrm{POY}$, containing turns in their loops, were considered. The $41 \%$ homologous 1X7F [29] was selected for actual modeling due to gapless alignment with bovine TyrRS linker (Fig. 1, c). For the N-domain we generated 10 models and selected a model number 8 as having the optimal Modeller objective function score and the best Biotech Validation Suite score (objective $=$ $=1490$, Biotech $=1.38$ ).

The $\mathrm{C}$-terminal domain was aligned with cytokinelike human 1NTG_A (Fig. 2,a) with $92 \%$ identity. Ten slightly different models of each domain were obtained. Selection of the models for future use was based on Biotech scores and Modeller objective function. A model number 5 was selected (objective $=934$, Biotech $=1.28$ ).

Modeling the interdomain linker of 17 aa was much more problematic. To model its structure we used two different approaches. A straightforward template-based approach commenced with BLAST search of all known linkers and identified a fragment of an auto-inhibitor of human C-Abl tyrosine kinase as the best template (PDB code 1OPL, chain A) [30]. To enable the modeling we added 5-aa overlaps to each side of the linker sequence. Resulting homology between the two sequences was 

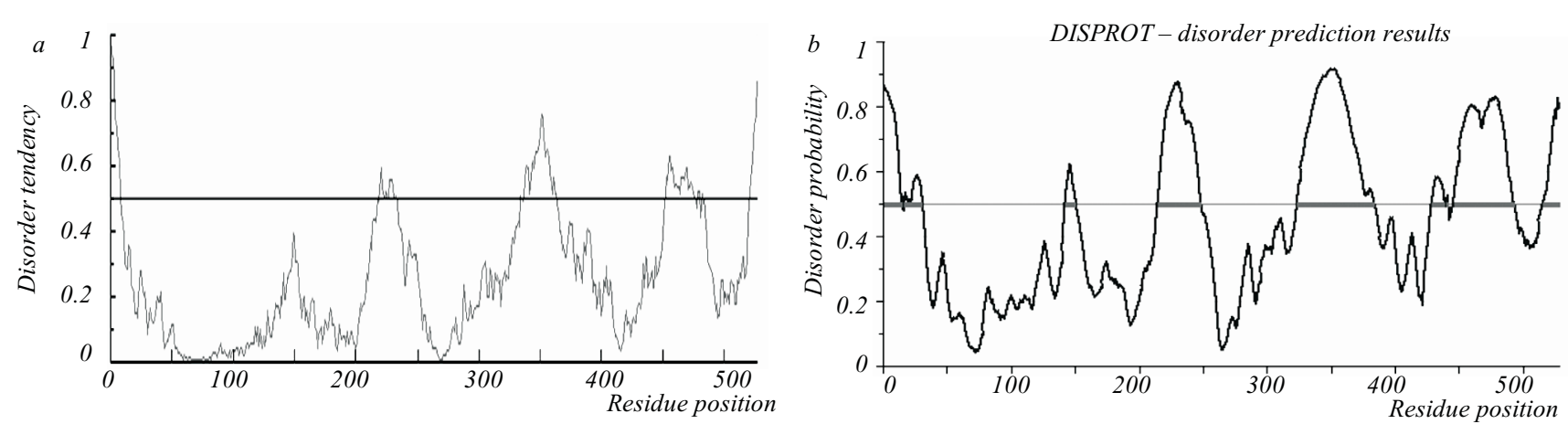

Fig. 3. Results of the bovine TyrRS protein intrinsically disordered region prediction by IUPRED [14] ( $a$ ) and by VSL2B program of DISPROT server [15] (b). The values above a middle line correspond to the intrinsically disordered regions of the protein

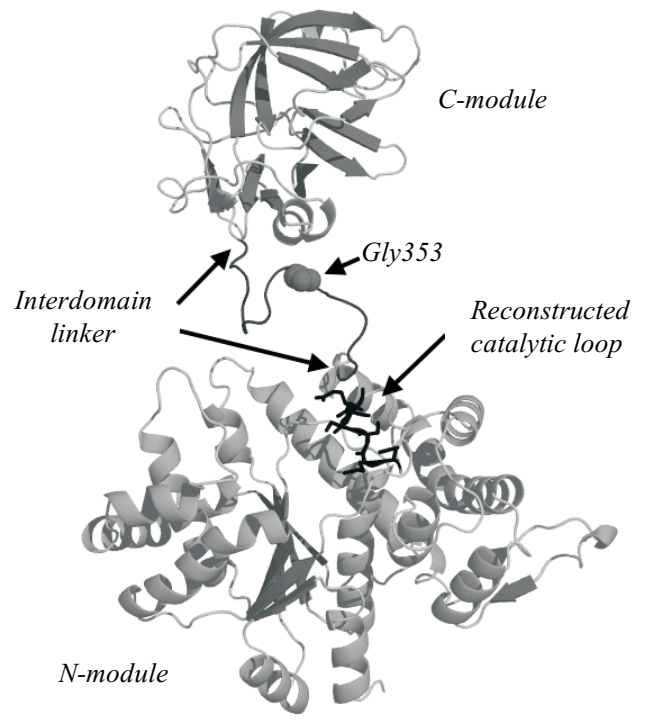

Fig. 4. Refined model Abl-17 of the full-length TyrRS colored according to secondary structure ( $\alpha$-helices, $\beta$-strands and turns are red, blue and grey respectively). The reconstructed catalytic loop is shown as blue sticks. The conservative glycine-353 in the interdomain linker is shown as green $\mathrm{vdW}$-spheres

only $34 \%$ (Fig. 1, d). The first model was selected from the ten models obtained, with objective $=3700$, Biotech $=1.20$. The $\mathrm{C}-\mathrm{Abl}$ kinase linker structure is shown in Fig. 2, $b$.

In order to model the full-length TyrRS protein we assembled all three parts (C-, and N-domains and linker) using Modeller 9.1. To get a realistic domain orientation we strived to obtain a maximum overlaps of the linker terminal amino acids backbone $\varphi$ and $\psi$ torsion angles with corresponding amino acids of domains being attached. All models were refined by energy minimization in Swiss-PDB Viewer [17] until their potential energy converged to an average value of approximately $-23700 \mathrm{~kJ} / \mathrm{mol}$.
Results and discussion. The failed efforts to crystallize full-length bovine TyrRS, as well as preliminary NMR data obtained in our laboratory (unpublished) made us suspect that the protein has intrinsically or transiently disordered regions. We have carried out bioinformatics analysis of potential TyrRS disorder. The data are analogous to those obtained for human TyrRS [31] and are shown in Fig. 3. The main unfolded regions correspond to the $\mathrm{N}$ - and C-termini, catalytic loop (Pro 216-Glu229) and interdomain linker (Pro342-Glu362) of the protein. The linker flexibility may be necessary for correct mutual orientation of $\mathrm{N}$ - and $\mathrm{C}$ - domains during tRNA $^{\text {Tyr }}$ binding and recognition. We decided to build an ensemble of possible linker conformations based on the homology with human C-Abl kinase linker (homology models will be further designated as Abl-X).

All homology models of full-length bovine TyrRS were generated in Modeller 9.1 from four components: $\mathrm{N}$-terminal domain, catalytic loop, linker structure and the $\mathrm{C}$-domain as described in Materials and methods. A selected model was refined by minimization in SwissPDB Viewer 4.0.1 (GROMOS96 43B1 parameter set) until its free energy reached a plateau. An average final energy for selected Abl-17 model was $-23700 \mathrm{~kJ} / \mathrm{mol}$. This model is characterized as extended («open») structure. It is possible that the solvated linker makes positive contribution to the overall structure free energy. The mutual orientation of two domains in Abl-17 is shown in Fig. 4.

Earlier, some putative tRNA ${ }^{\text {Tyr }}$ binding residues of the $\mathrm{C}$-domain were predicted from the tRNA ${ }^{\text {Phe }}$ and tRNA $^{\text {Tyr }}$ modification protection experiments [32]. Structural analysis of the tRNA-C-domain complex revealed a potential tRNA binding surface which consists of $\beta^{\prime} 1-\beta^{\prime} 2$ hairpin (Leu426-Gly433, Lys435-Gln437) 


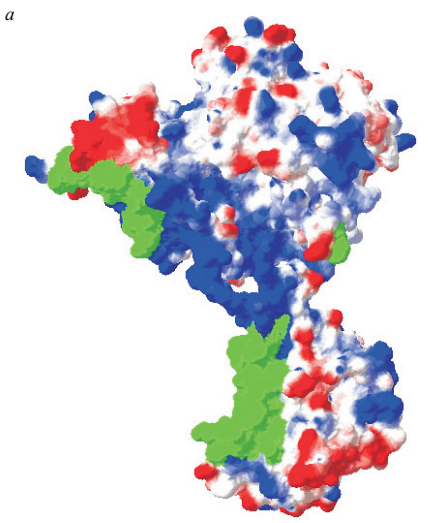

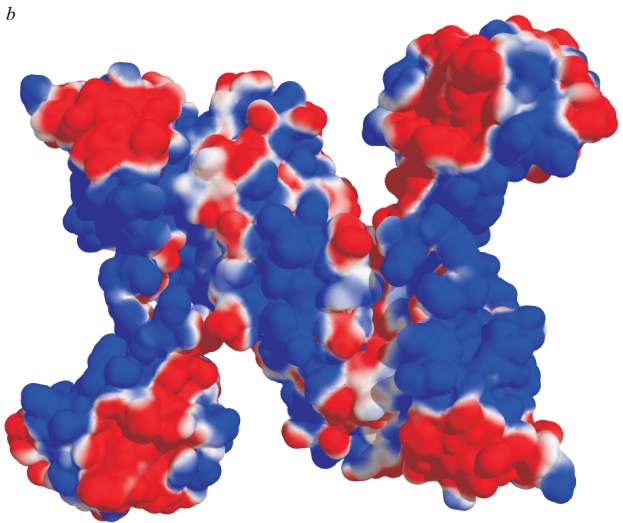

Fig. 5. $a$ - The molecular surface of Tyr RS Abl-17 model structure (the parts of Nand $\mathrm{C}$-modules which probably form the tRNA binding surface (His158, Lys 246-Pro252, Trp283, His305-Asp308, Lys 310, Leu426-Gly433, Lys435-Gln437, Glu480-Lys486, and Glu489-Lys490) are shown in green; positively charged residues are blue, negative - red); $b$ - the molecular surface of TyrRS dimer obtained by superimposition of Abl-17 model onto crystallographic model 1N3L (colour figure at www.biopolymers.org.ua) inserted into OB fold, interdomain region (Glu480Leu481), KPKKK lysine-rich cluster and Glu489Lys490 residues of the $\alpha$-helix of A-sub-domain. NDomain is responsible for the specific recognition and binding of L-tyrosine (residues Tyr39, Tyr166, Gln170, Asp173, and Gln188). The contact surface of the N-module with tRNA ${ }^{\mathrm{Tyr}}$ is formed by 14 aa, which are homologous to the corresponding residues in the yeast TyrRS (His158, Lys246-Pro252, Trp283, His305-Asp308, and Lys310) (Fig. 5, a). An evolutionary conservative Trp283 residue should form a stacking interaction with G34 of the tRNA, while a conservative Asp308 - hydrogen bonds with the same nucleotide.

We have superimposed the selected models on the crystallographic structure of the human TyrRS N-domain dimer $1 \mathrm{~N} 3 \mathrm{~L}$ with the $\mathrm{N}$-domain structure as a reference. Conformations of the side chains of initial mo$\mathrm{del}$, which made clashes on the interface of $\mathrm{N}$-modules in the dimer were optimized by Swiss-PdbViewer «simulated annealing» procedure. It was found that the Abl-17 structure had C-domain in the proximity with RNA binding surface of N-domain. The «open» structure of Abl-17 can form a large positively charged continuous RNA binding surface (Fig. $5, b$ ).

Since the flexibility of the linker is able to rotate around pivotal glycine-353 we do not consider the mutual domain orientation to be fixed. We have analyzed TyrRS interdomain linker sequences from 22 species of Metazoa (Fig. 6). In all Chordata the glycine position at the linker is absolutely conserved, which points out to its functional importance. Other Metazoa linkers also contain glycine, several amino acids shifted up- or downwards from the homologues of the Gly353. The shorter linker length in insects probably reflects a more ancient variant, while acquired prolines and lysines and linker extension in chordates result in more flexible linker backbone, probably needed for more adaptable interaction with different structural elements of tRNA ${ }^{\text {Tyr }}$.

It is possible that flexibility of the linker plays an important role in the interdomain communications and dynamic coupling/uncoupling between the $\mathrm{N}$ - and $\mathrm{C}$ domains, analogously to the effect observed in Csk kinase [33]. Class Ic of aminoacyl-tRNA synthetases recognizes the tRNA anticodon by one subunit and this «signal» has to be somehow transferred to the other subunit. There should be a mechanism of adaptable dynamic juxtaposition of the two subunits and the structural analysis of the interdomain linker gives us a hint at possible mechanism. The presence of four exposed lysine moieties in the linker of «open» conformation allows us to hypothesize a non-specific tRNA binding by the linker. On the other hand, the interdomain linker contains a proPEST motive and can be cleaved by proteases to release a cytokine-like $\mathrm{C}$-domain. The flexibility of the linker may modulate accessibility and exposure of this proteolysis site.

The full-length model of bovine TyrRS, as well as both its domains separately, can be used for further analysis and computational experiments, such as molecular docking with tRNA ${ }^{\mathrm{Tyr}}$, molecular dynamics simulations etc. Recently, we have performed an analysis of the YCD2 fragment of this model, comprised of the $\alpha$-helical part of $\mathrm{N}$-domain, the linker and the C-domain. The results reported in [34], revealed a specific behavior of the linker in ten-nanosecond time-frame. It changes conformation from extended and disordered to more compact one with short transient $\alpha$-helical structures, supporting the currently proposed general model 

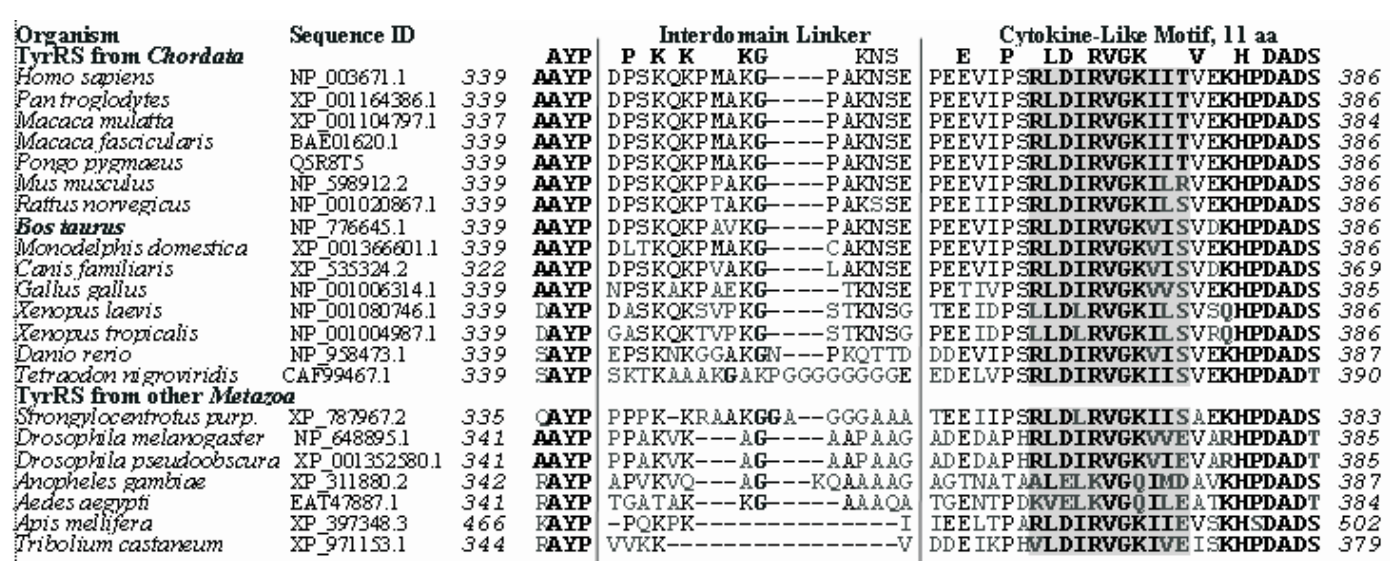

Fig. 6. Multiple alignment of the amino acid sequences of the interdomain linkers, flanking regions and C-terminal domain cytokine motives of the cytoplasmic TyrRS from 22 Metazoa species. The conservative glycines corresponding to the $B$. taurus linker residue Gly353 as well as absolutely conservative motives AAYP and KHPDADS are shown in boldface

of the interdomain linker role in modulation of the enzyme activity [35].

Future study on the full-length model of TyrRS molecules by molecular dynamics, with obtained structures as starting points, will hopefully allow us to suggest a mechanism of tyrosyl-tRNA synthetase action.

Acknowledgements. This work was supported by the National Academy of Sciences of Ukraine within the project «Dynamic aspects of functioning of eukaryotic tyrosyl-tRNA synthetase» (registration number 0107 U004938).

\section{М. О. Пидюра, О. І. Корнелюк}

Гнучка просторова структура Bos taurus тирозил-тРНК синтетази припускає існування шарнірного механізму, який забезпечується консервативним Gly353 у міждоменному лінкері

\section{Резюме}

Тирозил-тРНК синтетаза (TyrRS) ссавиів складається з двох структурних модулів: $N$-кінцевого каталітичного модуля (тіпі TyrRS) і некаталітичного иџитокін-подібного С-кінцевого модуля, з'єднаних гнучким пептидним лінкером. До сьогодні просторову структуру повнорозмірної TyrRS ссавців не вирішено методом рентгенівської кристалографії. Мета ичієї роботи полягала в моделюванні за гомологією просторової структури повнорозмірноі TyrRS B. taurus. Meтодu. Моделювання за гомологією TyrRS проведено з використанням Modeller 9.1. Якість моделей оцінювали за допомогою Biotech Validation Suite web-сервера. Результати. За даними BLAST-пошуку визначено 34 \%-ву гомологію послідовності міждоменного лінкера TyrRS i лінкера с-Abl тирозинкінази людини. Для моделювання структури повнорозмірної TyrRS ми зібрали модель з трьох фрагментів білка ( $N$-i C-кінцевих доменів $\mathrm{i}$ міждоменного лінкера), використовуючи Modeller 9.1. Кращу модель структури Abl-17 уточнено методом мінімізачії енергіï. Висновки. Висока гнучкість міждоменного лінкера може призводити до формування множинних конформацій TyrRS. Шарнірний механізм у міждоменному лінкері, вірогідно, забезпечується консервативним залишком Gly353. Передбачається, щчо завдяки високій гнучкості міждоменного лінкера відкрита конформаиія TyrRS може переходити в закриту конформацію у ферментносубстратних комплексах.
Ключові слова: тирозил-тРНК синтетаза, моделювання за гомологією, міждоменний лінкер, c-Abl тирозинкіназа, EMAP II, $m P H K^{T y r}$

\section{Н. А. Пидюра, А. И. Корнелюк}

Гибкая пространственная структура Bos taurus тирозил-тРНК синтетазы предполагает существование шарнирного механизма, обеспечиваемого консервативным Gly353 в междоменном линкере

Резюме

Тирозил-тРНК синтетаза (TyrRS) млекопитающих состоит из двух структурных модулей: N-конщевого каталитического модуля (тіпіTyrRS) и некаталитического иитокин-подобного C-концевого модуля, соединенных гибким пептидным линкером. До настоящего времени пространственная структура полноразмерной $T y r R S$ млекопитающих не решена методом рентгеновской кристаллографии. Цель данной работы состояла в моделировании по гомологии пространственной структуры полноразмерной TyrRS B. taurus. Методы. Моделирование по гомологии TyrRS выполнено с помощью пакета Modeller 9.1. Качество моделей оценивали с помощью Biotech Validation Suite web-сервера. Результаты. По данным BLAST-поиска определена 34 \%-я гомология последовательности междоменного линкера TyrRS и линкера c-Abl тирозинкиназы человека. Для моделирования структуры полноразмерной TyrRS, мы собрали модель из трех фрагментов белка $(N$ и C-кониевых доменов и междоменного линкера), используя Моdeller 9.1. Лучшая модель структуры Abl-17 уточнена методом минимизачии энергии. Выводы. Высокая гибкость междоменного линкера может приводить к формированию множественных конформаций TyrRS. Шарнирный механизм в междоменном линкере, вероятно, обеспечивается консервативным остатком Gly 353. Предполагается, что из-за высокой гибкости междоменного линкера открытая конформация TyrRS может переходить в закрытую конформачию в ферментно-субстратных комплексах.

Ключевые слова: тирозил-тРНК синтетаза, моделирование по гомологии, междоменный линкер, c-Abl тирозинкиназа, EMAP II, $m P H K^{T y r}$.

\section{REFERENCES}

1. Kornelyuk A. I. Structural and functional investigation of mammalian tyrosyl-tRNA synthetase // Biopolym. Cell.-1998.-14, N 4.-P. 349-359.

2. Gnatenko D. V., Kornelyuk A. I., Kurochkin I. V., Ribkinska T. A., Matsuka G. Kh. Isolation and characteristics of functionally acti- 
ve proteolytically modified form of tyrosyl-tRNA synthetase from bovine liver // Ukr. Biokhim. Zh.-1991.-63, N 4.-P. 61-67.

3. Levanets O. V., Naidenov V. G., Odynets K. A., Woodmaska M. I., Matsuka G. Kh., Kornelyuk A. I. Homology of C-terminal noncatalytic domain of mammalian tyrosyl-tRNA synthetase with cytokine EMAP II and non-catalytic domains of methionyl- and phenylalanyl-tRNA synthetases // Biopolym. Cell.-1997.-13, N 6.-P. 474-478.

4. Kleeman T. A., Wei D., Simpson K. L., First E. A. Human tyrosyl-tRNA synthetase shares amino acid sequence homology with a putative cytokine // J. Biol. Chem.-1997.-272, N 22.-P. 14420 14425.

5. Kao J., Ryan J., Brett G., Chen J., Shen H., Fan Y. G., Godman G., Familletti P. C., Wang F., Pan Y. C., Stern D., Clauss M. Endothelial monocyte-activating polypeptide II. A novel tumor-derived polypeptide that activates host-response mechanisms // J. Biol. Chem.-1992.-267, N 28.-P. 20239-20247.

6. Kao J., Houck K., Fan Y., Haehnel I., Libutti S. K., Kayton M. L., Grikscheit T., Chabot J., Nowygrod R., Greenberg S., Kuang W.-J., Leung D., Hayward J. R., Kisiel W., Heath M., Brett J., Stern D. M. Characterization of a novel tumor-derived cytokine. Endothelial monocyte-activating polypeptide II // J. Biol. Chem.1994.-269, N 40.-P. 25106-25119.

7. Tas M. P., Murray J. C. Endothelial monocyte-activating polypeptide II // Int. J. Biochem. Cell. Biol.-1996.-28, N 8.-P. 837841.

8. Ivakhno S. S., Kornelyuk O. I. Cytokine activities of some aminoacyl-tRNA synthetases and auxiliary cofactors of aminoacylation reaction // Exp. Oncol.-2004.-26, N 4.-P. 250-255.

9. Levanets O. V., Naidenov V. G., Woodmaska M. I., Matsuka G. H., Kornelyuk A. I. Cloning of cDNA encoding C-terminal part of mammalian tyrosyl-tRNA synthetase using of PCR-amplified radioactive probe // Biopolym. Cell.-1997.-13, N 2.-P. 121-126.

10. Simos G., Sauer A., Fasiolo F., Hurt E. C. A conserved domain within Arc1p delivers tRNA to aminoacyl-tRNA synthetases // Mol. Cell.-1998.-1, N 2.-P. 235-242.

11. Tan M., Heckmann K., Brunen-Nieweler C. The micronuclear gene encoding a putative aminoacyl-tRNA synthetase cofactor of the ciliate Euplotes octocarinatus is interrupted by two sequences that are removed during macronuclear development // Gene.1999.-233, N 1-2.-P. 131-140.

12. Simos G., Segref A., Fasiolo F., Hellmuth K., Shevchenko A., Mann M., Hurt E. C. The yeast protein Arc1p binds to tRNA and functions as a cofactor for the methionyl- and glutamyl-tRNA synthetases // EMBO J.-1996.-15, N 19.-P. 5437-5448.

13. Kurochkin I. V., Kornelyuk A. I., Matsuka G. Kh. Interaction of eukaryotic tyrosyl-tRNA synthetases with high molecular weight RNA // Mol. Biol. (Moscow).-1991.-25, N 3.-P. 779-786.

14. Peng K., Radivojac P., Vucetic S., Dunker A. K., Obradovic Z. Length-dependent prediction of protein intrinsic disorder // BMC Bioinformatics.-2006--7.-P. 208.

15. Dosztanyi Z., CsizmokV., Tompa P., Simon I. Web server for the prediction of intrinsically unstructured regions of proteins based on estimated energy content // Bioinformatics.-2005.-21, N 16.P. 3433-3434.

16. Berman H. M., Westbrook J., Feng Z., Gilliland G., Bhat T. N., Weissig H., Shindyalov I. N., Bourne P. E. The protein data bank // Nucleic Acids Res.-2000.-28, N 1.-P. 235-242.

17. Guex N., Peitsch M. C. SWISS-MODEL and the Swiss-PdbViewer: an environment for comparative protein modeling // Electrophoresis.-1997.-18, N 15.-P. 2714-2723.

18. DeLano W. L. The PyMOL Molecular Graphics System.-San Carlos: DeLano Scientific, 2002
19. Persistence of Vision Pty. Ltd, Persistence of Vision Raytracer (Version 3.6).-2004.

20. Baker N. A., Sept D., Joseph S., Holst M. J., McCammon J. A. Electrostatics of nanosystems: application to microtubules and the ribosome // Proc. Natl Acad. Sci. USA.-2001.-98, N 18.P. 10037-10041.

21. Holst M., Saied F. Numerical solution of the nonlinear PoissonBoltzmann equation: Developing more robust and efficient methods // J. Comput. Chem.-1995.-16, N 3.-P. 337-364.

22. Elofsson A., Fischer D., Rice D. W., Le Grand S. M., Eisenberg $D$. A study of combined structure/sequence profiles // Fold Des.1996.-1, N 6.-P. 451-461.

23. Larkin M. A., Blackshields G., Brown N. P., Chenna R., McGettigan P. A., McWilliam H., Valentin F., Wallace I. M., Wilm A., Lopez R., Thompson J. D., Gibson T. J., Higgins, D. G. Clustal $\mathrm{W}$ and Clustal X version 2 // Bioinformatics.-2007.-23, N 21.P. 2947-2948.

24. Goujon M., McWilliam H., Li W., Valentin F., Squizzato S., Paern $J$., Lopez R. A new bioinformatics analysis tools framework at EMBL-EBI // Nucleic Acids Res.-2010.--38 (Web Server issue).W695-699.

25. Fiser A., Sali A. Modeller: generation and refinement of homology-based protein structure models // Methods Enzymol.-2003.374.-P. 461-491.

26. Laskowski R. A., MacArthur M. W., Moss D. S., Thornton J. M. PROCHECK: a program to check the stereochemical quality of protein structures // J. Appl. Cryst.-1993.-26, N 2.-P. 283-291.

27. Yang X. L., Skene R. J., McRee D. E., Schimmel P. Crystal structure of a human aminoacyl-tRNA synthetase cytokine // Proc. Natl Acad. Sci. USA.-2002.-99, N 24.-P. 15369-15374.

28. Yang X. L., Liu J., Skene R. J., McRee D. E., Schimmel P. Crystal structure of an EMAP-II-like cytokine released from a human tRNA synthetase // Helv. Chim. Acta.-2003.-86, N 4.-P. 1246 1257.

29. Minasov G., Shuvalova L., Brunzelle J. S., Collart F. R., Anderson W. F., Mcsg. Crystal structure of an uncharacterized B. cereus protein // PDB: $1 \mathrm{X} 7 \mathrm{~F}$.

30. Nagar B., Hantschel O., Young M. A., Scheffzek K., Veach D., Bornmann W., Clarkson B., Superti-Furga G., Kuriyan J. Structural basis for the autoinhibition of c-Abl tyrosine kinase // Cell.2003.-112, N 6.-P. 859-871

31. Odynets K. A., Kornelyuk A. I. Analysis of unstructured regions of human cytoplasmic tyrosyl-tRNAsynthetase by methods of bioinformatics // Biopolym. Cell.-2005.-21, N 5.-P. 445-452.

32. Olszak K., Solecka K., Odynets K. A., Przykorska A., Kornelyuk A. $I$. The analysis of the complex between cytokine-like $\mathrm{COOH}-$ terminal module of mammalian tyrosyl-tRNA synthetase and tRNA // Abstrs of the $29^{\text {th }}$ Meet. of FEBS.-Warsaw, 2004.-P. 54.

33. Wong L., Lieser S., Chie-Leon B., Miyashita O., Aubol B., Shaffer J., Onuchic J. N., Jennings P. A., Woods V. L. Jr., Adams J. $A$. Dynamic coupling between the SH2 domain and active site of the COOH terminal Src kinase, Csk // J. Mol. Biol.-2004.-341, N 1.-P. 93-106.

34. Pydiura N. A., Tereshchenko F. A., Kornelyuk A. I. Conformational flexibility of interdomain linker in bovine tyrosyl-tRNA synthetase studied by molecular dynamics simulation // Biopolym. Cell.-2006.-22, N 6.-P. 433-438.

35. Wriggers W., Chakravarty S., Jennings P. A. Control of protein functional dynamics by peptide linkers // Biopolymers.-2005.80, N 6.-P. 736-746.

Received 25.07.12 